\title{
Assessing Residential Satisfaction by Level of Residence in Off-Campus Environment
}

\author{
Muhammad Hilmy Muslim, Hafazah Abdul Karim, \\ Ishak Che Abdullah, Puziah Ahmad \\ Faculty of Architecture, Planning and Surveying, \\ Universiti Teknologi MARA, Shah Alam 40450, Malaysia \\ hilmymuslim89@gmail.com
}

\begin{abstract}
This study aims to clarify the explanatory factors and the extent to which those factors help to predict the overall residential satisfaction among students living off-campus. This survey utilized a stratified sample of individuals with a questionnaire which was administered to 341 non-resident (NR) students, in seven groups of neighborhoods in the city of Shah Alam. In the analytic process, a Factor Analysis procedure is applied to reduce the data set and to uncover the relationships between various factors and dimensions of the students' residential satisfaction. Descriptive results show a degree of satisfaction with each level of the residential environment.
\end{abstract}

Keywords: Residential satisfaction; levels of environment; off-campus environment

eISSN 2398-4295 @ 2018. The Authors. Published for AMER ABRA cE-Bs by e-International Publishing House, Ltd., UK. This is an open-access article under the CC BY-NC-ND license (http://creativecommons.org/licenses/bync-nd/4.0/). Peer-review under responsibility of AMER (Association of Malaysian Environment-Behaviour Researchers), ABRA (Association of Behavioural Researchers on Asians) and cE-Bs (Centre for EnvironmentBehaviour Studies), Faculty of Architecture, Planning \& Surveying, Universiti Teknologi MARA, Malaysia.

DOI: http://dx.doi.org/10.21834/ajbes.v3i10.76 


\subsection{Introduction}

The current trend of higher education institution development and rapid enrolment changes had a significant impact on urban areas specifically on residential environment. Urban areas with densely packed housing stock has transformed into sprawling off-campus residential areas for students. This process is supposed to have density pressures and can stimulate social isolation and the widening socio-spatial polarization of different social groups, indirectly would impact the students' quality of life.

In preventing the phenomenon getting worse, the university should control and monitor the quality of the residential environment with regard to off-campus student. Therefore, this study aims to determine the level of residential satisfaction among off-campus students in Shah Alam to explain the descriptive factors and the level to which individuals factors help to predict residential satisfaction as a major important element of this population group's quality of life.

\subsection{Literature Review}

The term 'residential satisfaction' used in studies of the house and their sphere of place, refers to individuals' appraisal of the conditions of their residential environment, in relation to their needs, expectations and achievements (Amérigo, 1990; Amérigo \& Aragonés, 1997; Anderson \& Weidemann, 1997; Weidemann \& Anderson, 1985). Studies in residential satisfaction must include both space and residents as users of this space (Adriaanse, 2007; Berkoz \& Kellekci, 2007). The residential area is not limited to the house but also expand to the environment where it is situated and the residents who live there because the off-campus student's experience with their neighborhood and neighbors may be just as important as their house itself (Aiello, Ardone, \& Scopelliti, 2010; Bonaiuto, Aiello, Perugini, Bonnes, \& Ercolani, 1999; Bonaiuto, Fornara, \& Bonnes, 2003; Dasimah et al., 2011; Fleury-Bahi, Félonneau, \& Marchand, 2008; Fornara, Bonaiuto, \& Bonnes, 2010; Mohit, Ibrahim, \& Rashid, 2010; Oktay \& Rustemli, 2011; Parkes, Kearns, \& Atkinson, 2002).

The studies of residential satisfaction are usually measured by residences as the overall environment. Most researchers focus on how satisfied residents are with the assessment of their home environment in general (Ahmad Hariza, 2003; Aiello et al., 2010; Fleury-Bahi et al., 2008; Kahana, Lovegreen, Kahana, \& Kahana, 2003; Kahrik, Leetmaa, \& Tammaru, 2012; Mohit et al., 2010; Nurul 'Ulyani, Nor' Aini, \& Nazirah, 2011). This indicates that they have assumed that housing satisfaction is the same across different spaces or different 'levels of environment'. However, Canter and Rees (1982) have argued that humans interact in the environment at different levels, from the bedroom to the neighborhood, hence throughout the city. In their model of housing satisfaction, Canter and Rees (1982) refers to the 'levels of the environment' as the interaction of the environment level and the environment is defined as the scale of a hierarchy order. They specified the different levels that a resident may experience satisfaction such as the house and neighborhood.

The relationship between satisfaction and levels of the environment is also yet to be extensively examined empirically in satisfaction studies. Specifically, two issues need to be examined critically in this regard. The first is whether satisfaction is distinctly and significantly 
different at different levels of the environment and whether it has an order to it as suggested by Canter and Rees (1982) and Bonaiuto et al. (1999). The second is whether 'dimensions of satisfaction' are similar at the different levels of the environment. The term 'dimensions of satisfaction' refers to the aspects, characteristics, and features of the residential environment (such as social, spatial, contextual and functional) to which the users respond in relation to satisfaction (Fornara et al., 2010; Muslim, Karim, \& Abdullah, 2012a, 2012b). This is essential because it would inform researchers about the important dimensions at different levels of the environment.

This paper examines these issues in the context of off-campus students' residences in Shah Alam, Malaysia. Specifically, the aim of the study is first to empirically identify the levels of environment along which students respond to their residences and compare them with those naturally implied in the environmental behavior of the residences. Second, it examines whether there is significant differences and hierarchy in satisfaction at the different levels of environment identified. Finally, it examines how similar or different dimensions of satisfaction are at the different levels of environment.

\subsection{Methodology}

The questionnaire survey method was adopted. The respondents were selected from seven groups of neighborhood among off-campus residence using a stratified sampling procedure. The stratified sampling method ensured that category of off-campus students (by type of house) were selected. Based on the total number of NR students in Management Unit of NR (MUNR) database, there were 11,677 students who live off-campus, but after selected the certain criteria of students who were lived around the campus, only 2,993 from population are valid for the study. However, the actual survey will only use a total of 341 respondents, calculated with 95 percent confidence level and 5 percent sampling error.

Three types of data analysis were performed. First, the 69 items on satisfaction were reduced to smaller factors using factor analysis. The aim was to find whether the factors that emerge would reflect distinct levels of environment and at which levels of environment would be reflected. Second, a relative satisfaction index was computed for each of the levels of the environment identified from the previous analysis. These were computed as the mean scores of the responses to the questions on satisfaction at each level. The intention was to examine whether there would be a hierarchical order to satisfaction and whether there would be any significant difference between the levels of satisfaction at these three levels of the residence. Finally, factor analyses were performed for each of the sets of satisfaction questions comprising each level to examine whether the emerging new factors were similar or different across the levels.

\subsection{Results and Discussions}

The results of the factor analysis of the 69 items on satisfaction with residence (Error! Reference source not found.) produced thirteen factors and explained 74.623 percent of the variance. 
Table 1. Factor Analysis of Satisfaction Variables

\begin{tabular}{|c|c|}
\hline Factor and Variance $(\%)$ & Factor Loading \\
\hline Factor 1 (Neighborhood environment) & $(13.723 \%)$ \\
\hline No vandalism activities & .787 \\
\hline Difficult to find bad people/ criminals & .780 \\
\hline Well-maintained road signage & .773 \\
\hline Residence concerned about their neighborhoods' environment & .758 \\
\hline Unpolluted neighborhood & .742 \\
\hline Road usually cleansed in this neighborhood & .742 \\
\hline No risk of danger at night & .735 \\
\hline The neighborhood is not noisy & .720 \\
\hline Clean neighborhood environment & .684 \\
\hline Tranquil atmosphere of neighborhood & .629 \\
\hline Very happy live in current neighborhood & .503 \\
\hline Factor 2 (House environment) ${ }^{*}$ & $(9.768 \%)$ \\
\hline Comfortable dwelling space for relaxing & .783 \\
\hline Large dwelling space to put things & .755 \\
\hline Comfortable dwelling space for studying & .743 \\
\hline Having privacy between housemates & .718 \\
\hline Comfortable studying with friends in home & .689 \\
\hline Comfortable with shared bedroom & .682 \\
\hline Dwelling environment can be adapted to personal lifestyle & .667 \\
\hline No sleep conflict between housemates & .623 \\
\hline Interior physical condition of the house is beautiful or newly renovated & .619 \\
\hline Good safety of dwelling condition & .541 \\
\hline Welcome the guests / friend comes into dwelling & .528 \\
\hline Factor 3(Neighbor sociability) ${ }^{n}$ & $(8.573 \%)$ \\
\hline Involved with the neighborhood activities & .832 \\
\hline Participate activities organized by neighborhood society & .798 \\
\hline Recognize the next door neighbor & .761 \\
\hline Easy to know in common residents & .722 \\
\hline Establishing good relations between neighbors & .716 \\
\hline Neighborhood residents tend to stand united & .685 \\
\hline Easy to find new friends in neighborhood & .616 \\
\hline Do sports and recreational activities & .570 \\
\hline Do worship and religious activities & .530 \\
\hline Factor 4 (Green areas) ${ }^{* * *}$ & $(6.737 \%)$ \\
\hline Easily to get to the open space / green & .798 \\
\hline Open/green space in good condition & .785 \\
\hline Enough open/green space & .784 \\
\hline Equipped with sports courts & .672 \\
\hline Ability to do a variety of sports and recreational activities & .669 \\
\hline There are special areas for outdoor sport & .614 \\
\hline Factor 5 (Public transportation) ${ }^{* *}$ & $(6.034 \%)$ \\
\hline Sufficient frequency of public transport for residents demand & .889 \\
\hline Comfortable bus services & .858 \\
\hline Good connectivity to other areas by public transportation & .851 \\
\hline Good placement of bus stops & .839 \\
\hline Factor 6 (Neighborhood attachment) ${ }^{* *}$ & $(5.826 \%)$ \\
\hline There is no other area can be compared with this neighborhood & .705 \\
\hline This neighborhood is the most ideal for me & .700 \\
\hline Strong sense of belonging in this neighborhood & .691 \\
\hline Will be difficult for me to leave this neighborhood & .676 \\
\hline I do not want to live in other neighborhood & .656 \\
\hline The neighborhood is important matter in my life & .588 \\
\hline
\end{tabular}




\begin{tabular}{|c|c|}
\hline Factor 7 (Religious facilities) ${ }^{* \star *}$ & $(4.381 \%)$ \\
\hline Mosque easy to reach by walking & .806 \\
\hline This neighborhood has a good religious facilities & .797 \\
\hline Mosque actively conducting religious activities & .754 \\
\hline Factor 8 (Commercial services) & $(4.049 \%)$ \\
\hline Good commercial services & .851 \\
\hline Variety goods are available in shops & .833 \\
\hline Good placement of shops & .658 \\
\hline Factor 9 (City connection) & $(4.010 \%)$ \\
\hline This neighborhood is well connected to the city centre & .578 \\
\hline Easily to commuting into the university & .568 \\
\hline Easily reach to city centre from dwelling & .566 \\
\hline Factor 10 (Accessibility) ${ }^{\text {\#* }}$ & $(3.945 \%)$ \\
\hline Good provision of parking space & .767 \\
\hline Traffic circulations are very smooth & .654 \\
\hline Easily to move around the city & .572 \\
\hline Factor 11 (Housing facilities) ${ }^{*}$ & $(2.890 \%)$ \\
\hline Equipped furniture & .713 \\
\hline Good provision of kitchen equipment & .649 \\
\hline Smooth internet access at dwelling & .540 \\
\hline Factor 12 (Stimulating) & $(2.533 \%)$ \\
\hline This neighborhood is full of beneficial activities & .706 \\
\hline Every day, this neighborhood has something interesting & .585 \\
\hline Factor 13 (Discretion) & $(2.154 \%)$ \\
\hline Residents in this neighborhood do not interfere with each other & .578 \\
\hline $\begin{array}{l}\text { Total variance explained }=74.623 \% \\
\text { Factors related to the house level } \\
\text { Factors related to the neighborhood level } \\
\text { Factors related to the city level }\end{array}$ & \\
\hline
\end{tabular}

(Source: Muslim, Karim, Abdullah, and Ahmad (2013))

All 13 factors had eigenvalues of 1.00 or more and only the variables with factor loading of more than 0.500 were selected. The results showed that variables that comprised each factor were highly related, and it was not difficult to describe which level of environment each factor represented.

This was because the factors were either describing specific attributes at a particular level of the environment or they were describing a level of the environment itself. Three levels of environment could be clearly identified from these factors: the house, the neighborhood, and the city. Factors 2 and 11 were related to the house while factors $1,3,6,12$ and 13 were related to the neighborhood. The other factor, namely: factor 4, 5, 7, 8, 9 and 10 referred to the level of the city. These results are quite instructive because they suggest that although location and levels of the environment are intricately bound with individual's evaluation of residential environments, they are still exclusive, and they would emerge in user responses. Satisfaction studies therefore need to account for levels of environment and, in contexts similar to that of this study, the three levels identified above need to be considered.

The level of the neighborhood appeared to be the most important level of environment because the largest variance $(13.723 \%)$ was accounted for by the factor that defined this level. This proportion is more than one-sixth of the total variance of all the 13 factors (74.623\%). The finding is consistent with previous studies that classified the neighborhood 
as a most important area and also noted that this area is usually psychologically very important to the resident (Werner \& Altman, 1985).

The ease with which levels of the environment could be identified from the factors was an indication of the distinct nature of these levels. Nevertheless, whether the levels were significantly different was also tested statistically. First, satisfaction at the three levels of environment identified was examined by computing satisfaction indices for all the respondents at each of these levels. Three satisfaction indices, RSh, RSn, and RSc were computed for each respondent at the level of the house, the neighbor, and the city, respectively. The satisfaction indices were computed as the mean score of each respondent's responses to 14 of house attributes, 32 of neighborhood attributes, and 23 of city attributes.

The results (Table 2) showed that the proportion of individuals who were dissatisfied was highest at the neighborhood.

Table 2. Residential satisfaction at three levels of residence

\begin{tabular}{llllllll}
\hline $\begin{array}{l}\text { Level of } \\
\text { residence }\end{array}$ & $\begin{array}{l}\text { Strongly } \\
\text { dissatisfied } \\
(\%)\end{array}$ & $\begin{array}{l}\text { Dissatisfied } \\
(\%)\end{array}$ & $\begin{array}{l}\text { Slightly } \\
\text { dissatisfied } \\
(\%)\end{array}$ & $\begin{array}{l}\text { Neutral } \\
(\%)\end{array}$ & $\begin{array}{l}\text { Slightly } \\
\text { satisfied } \\
(\%)\end{array}$ & $\begin{array}{l}\text { Satisfied } \\
(\%)\end{array}$ & $\begin{array}{l}\text { Strongly } \\
\text { satisfied } \\
(\%)\end{array}$ \\
\hline $\begin{array}{l}\text { Satisfaction with } \\
\text { house (RSh) }\end{array}$ & 8.7 & 9.0 & 12.9 & 24.0 & 17.2 & 19.0 & 9.2 \\
$\begin{array}{l}\text { Satisfaction with } \\
\text { neighbourhood }\end{array}$ & 13.5 & 12.3 & 17.0 & 28.2 & 13.0 & 11.0 & 5.0 \\
$\begin{array}{l}\text { (RSn) } \\
\begin{array}{l}\text { Satisfaction with } \\
\text { city (RSc) }\end{array}\end{array}$ & 9.1 & 9.9 & 15.5 & 24.0 & 17.6 & 14.6 & 9.3 \\
\hline
\end{tabular}

(Source: Muslim et al. (2013))

The proportions of those who were strongly dissatisfied, dissatisfied and slightly dissatisfied with the attributes of the house, the attributes of the neighborhood, and the attributes of the city were 30.6 percent, 42.8 percent, and 35.3 percent respectively. These results suggested that there was not a hierarchal order to these levels. The order of satisfaction decreased from the neighborhood to the house and then to the city, and dissatisfaction increased in the same manner. This shows that, residential satisfaction for students' with regard to the off-campus environment not significantly influenced at the city level of environment. It appeared that the residents responded to similar dimensions of the environment at each level.

The results of the dimensions of satisfaction are presented in Tables 3, 4, and 5 . These tables present the dimensions in relation to the satisfaction that emerged from the factor analyses at each level of the environment. First of all, it appeared that the emerging factors from the analysis explained the data fairly well because the variance explained was about 70 percent on the average. Hence the results are quite useful. To define the dimension of each factors, the components of the factors were examined whether related to spatial, social, functional, contextual or other dimensions.

In general, it appeared that the dimensions of satisfaction were quite dissimilar across the three levels. The dimensions of social were common to all levels. Hence, it may be 
concluded that the residents responded on the contrary at each of the levels of the environment. However, a specific difference was found across the levels of environment in this analysis. It was found that the first factor that is house environment, the most important dimension that accounted for the highest variance, was relatively different across the different levels.

Table 3. Dimension of satisfaction at house level

\begin{tabular}{llll}
\hline Factor & $\begin{array}{l}\text { Factor } \\
\text { Loading }\end{array}$ & Dimension & $\begin{array}{l}\text { Explained } \\
\text { Variance (\%) }\end{array}$ \\
\hline Factor 1 (house environment) & .774 & Social/ Spatial & $51.086 \%$ \\
Having privacy between housemates & .758 & \\
There is no sleep conflict between housemates & .739 & \\
Comfortable dwelling space for relaxing & .729 & \\
Large dwelling space to put things & .667 & \\
Comfortable studying with friends in home & .658 & \\
Dwelling environment can be adapted to personal & .627 & \\
lifestyle & .624 & \\
Welcome the guests / friend comes into dwelling & .618 & \\
Comfortable dwelling space for studying & .567 & \\
Still feel comfortable even sharing a bedroom & & \\
Interior physical condition of the house is beautiful or & $.568 \%$ \\
newly renovated & & \\
\hline Factor 2 (housing facilities) & .810 & \\
Equipped furniture & .781 & \\
Good provision of kitchen equipment & .696 & \\
Smooth internet access at dwelling & .518 & \\
Good safety of dwelling condition & & \\
\hline Total explained variance = 60.374 \% & & \\
\hline
\end{tabular}

(Source: Muslim et al. (2013))

Spatial issues were the most important dimension at the level of the house, whereas social were the most important dimension at the level of the neighborhood, and functional is important dimensions at the level of the city (refer to Table 3, Table 4 and Table 5 respectively). These shown that certain factors are more important than others in determining satisfaction between the housing unit and the neighborhood. This finding is also another indication of the difference in satisfaction across the levels. It thus appears that the dimensions to which off-campus students responded in relation to satisfaction were dissimilar at all levels of the environment and also dissimilar in relative importance.

\subsection{Conclusion}

This study examines satisfaction at different levels of environment in the context of off-campus students' residences. Indeed, residents' satisfaction with these offcampus housing environment in relation to levels of environment was not quite the same as what was implied by the residence sociability. 
Table 4. Dimension at neighborhood level

\begin{tabular}{|c|c|c|c|}
\hline Factor & Factor Loading & Dimension & $\begin{array}{l}\text { Explained } \\
\text { Variance }(\%)\end{array}$ \\
\hline Factor 1 (neighborhood environment) & & Contextual/ & $43.426 \%$ \\
\hline The neighborhood is generally not polluted & .815 & Social & \\
\hline Clean environment in this neighborhood & .810 & & \\
\hline This neighborhood is not noisy & .800 & & \\
\hline There is no vandalism activities in this neighborhood & .770 & & \\
\hline This neighborhood have a tranquil atmosphere & .764 & & \\
\hline $\begin{array}{l}\text { Difficult to find bad people / criminals in this } \\
\text { neighborhood }\end{array}$ & .749 & & \\
\hline Road signage well maintained in this neighborhood & .748 & & \\
\hline $\begin{array}{l}\text { After dark, there is no risk of danger ahead in this } \\
\text { neighborhood }\end{array}$ & .731 & & \\
\hline $\begin{array}{l}\text { Residents are concerned about their neighborhoods' } \\
\text { environment }\end{array}$ & .726 & & \\
\hline Roads usually cleansed in this neighborhood & .695 & & \\
\hline Happy living in this neighborhood & .547 & & \\
\hline Factor 2 (neighbors' interaction) & & Social/ & $10.775 \%$ \\
\hline Involved with the neighborhood activities & .885 & Contextual & \\
\hline $\begin{array}{l}\text { Attend meetings of activities organized by } \\
\text { neighborhood society }\end{array}$ & .851 & & \\
\hline Recognize the next door neighbor & .802 & & \\
\hline Establishing good relations between neighbors & .714 & & \\
\hline In this neighborhood, residents tend to stand united & .698 & & \\
\hline $\begin{array}{l}\text { In this neighborhood, it's easy to know in common } \\
\text { the residents }\end{array}$ & 677 & & \\
\hline In this neighborhood, it's easy to find new friends & .545 & & \\
\hline Factor 3 (neighborhood attachment) & & Contextual & $5.871 \%$ \\
\hline This is the ideal neighborhood to live in & .753 & & \\
\hline $\begin{array}{l}\text { It would be very hard for me to leave this } \\
\text { neighborhood }\end{array}$ & .752 & & \\
\hline $\begin{array}{l}\text { I would not willingly leave this neighborhood for } \\
\text { another }\end{array}$ & .727 & & \\
\hline $\begin{array}{l}\text { There is no other neighborhood can be compared } \\
\text { with this neighborhood }\end{array}$ & .727 & & \\
\hline Strong sense of belonging in this neighborhood & .723 & & \\
\hline Now this neighborhood is part of my life & .641 & & \\
\hline Factor 4 (discretion) & & Social & $4.337 \%$ \\
\hline In this neighborhood, always feel observed & .760 & & \\
\hline $\begin{array}{l}\text { Residents in this neighborhood do not interfere with } \\
\text { each other }\end{array}$ & .693 & & \\
\hline Residents too take cognizance of each other & .552 & & \\
\hline Factor 5 (stimulating) & & Social & $3.763 \%$ \\
\hline This neighborhood is full of beneficial activities & .809 & & \\
\hline $\begin{array}{l}\text { Every day, this neighborhood has something } \\
\text { interesting }\end{array}$ & .657 & & \\
\hline Factor 6 (general students' activities) & & Social & $3.368 \%$ \\
\hline Hanging out with friends in cafes' and restaurants & .812 & & \\
\hline Do sports and recreational activities & .557 & & \\
\hline Do worship and religious activities & .518 & & \\
\hline
\end{tabular}

(Source: Muslim et al. (2013)) 
Table 5. Dimension of satisfaction at city level

\begin{tabular}{|c|c|c|c|}
\hline Factor & $\begin{array}{l}\text { Factor } \\
\text { Loading }\end{array}$ & Dimension & $\begin{array}{l}\text { Explained } \\
\text { Variance (\%) }\end{array}$ \\
\hline Factor 1 (community facilities) & & $\begin{array}{l}\text { Functional/ } \\
\text { Spatial }\end{array}$ & $38.328 \%$ \\
\hline Open/green space in good condition & .878 & & \\
\hline Easily to get to the open space / green & .877 & & \\
\hline There is enough open/green space & .868 & & \\
\hline $\begin{array}{l}\text { Ability to do a variety of sports and recreational } \\
\text { activities }\end{array}$ & .814 & & \\
\hline Equipped with sports courts & .798 & & \\
\hline Special areas for outdoor sport & .793 & & \\
\hline Mosque actively conducting religious activities & .537 & & \\
\hline Good religious facilities & .520 & & \\
\hline Factor 2 (transportation services) & & Functional & $17.996 \%$ \\
\hline Sufficient public transport frequency & .898 & & \\
\hline Comfortable bus services & .873 & & \\
\hline Good placement of bus stops & .860 & & \\
\hline $\begin{array}{l}\text { Good connectivity to other areas by public } \\
\text { transportation }\end{array}$ & .859 & & \\
\hline Factor 3 (city connection) & & Spatial & $8.365 \%$ \\
\hline Easily reach to city centre from dwelling & .837 & & \\
\hline Easily to commuting into the university & .815 & & \\
\hline $\begin{array}{l}\text { The neighborhood is well connected to the city } \\
\text { centre }\end{array}$ & .766 & & \\
\hline Easily to move within the city & .631 & & \\
\hline Mosque easy to reach by walking & .536 & & \\
\hline Factor 4 (commercial services) & & Functional & $7.492 \%$ \\
\hline Good commercial service & .878 & & \\
\hline The availability of the variety of goods & .868 & & \\
\hline Good location for the placement of shops & .742 & & \\
\hline Factor 5 (accessibility) & & Contextual & $4.943 \%$ \\
\hline Good provision of parking space & .687 & & \\
\hline Smooth traffic circulations & .636 & & \\
\hline Adequate street lighting & .617 & & \\
\hline
\end{tabular}

(Source: Muslim et al. (2013))

This implies that studies should not assume the levels of the environment to which residents may respond either from the configuration of the spatial environment or otherwise, but rather should identify levels through the residents' responses, especially in housing environments such as this. In addition, it suggests that studies in similar contexts as this should take account of the two levels of the environment (house and neighborhood) identified in this study 
as important levels along which students relate to their environment. It is however important to note that levels of the environment are very context specific and more or fewer levels may be present in other students' residences in other contexts.

Finally, the study reveals that residents respond to dissimilar dimensions of satisfaction across the levels of the environment but that the dimension that is most important differs at each level. Hence, studies that evaluate satisfaction or other responses to this off-campus environment may safely investigate the same dimensions across different levels. In addition, these results imply that the sociability of students' housing should account for the two levels identified in this study (house and neighborhood) as well as the different dimensions that are important at each level of the environment. In summation, the study shows that residents respond to two levels of environment. The experience of satisfaction at these levels of the environment is significantly different and not necessarily hierarchal. However, the dimensions to which residents respond with respect to satisfaction are the same.

\section{Acknowledgement}

The authors acknowledged the financial support provided by the Research Management Institute of Universiti Teknologi MARA, Malaysia for this research under Research Intensive Faculty grant [Project Code: 600-RMI/DANA 5/3/RIF (281/2012)].

\section{References}

Adriaanse, C. C. M. (2007). Measuring residential satisfaction: a residential environmental satisfaction scale (RESS). Journal of Housing and the Built Environment, 22(3).

Ahmad Hariza, H. (2003). Residential Satisfaction and Social Integration in Public Low Cost Housing in Malaysia. Pertanika Journal Social Science \& Humanities, 11(1), 1-10.

Aiello, A., Ardone, R. G., \& Scopelliti, M. (2010). Neighbourhood planning improvement: Physical attributes, cognitive and affective evaluation and activities in two neighbourhoods in Rome. Evaluation and Program Planning, 33(3), 264-275. doi: 10.1016/j.evalprogplan.2009.10.004

Amérigo, M. a. (1990). The perception of residential environment and environment role. In R. Pamir, V. luramoglu \& N. Teymur (Eds.), Culture, Space and History (Vol. V). Ankara: M.E.T.V.: Faculty ofArchitecture.

Amérigo, M. a., \& Aragonés, J. I. (1997). A Theoretical And Methodological Approach To The Study Of Residential Satisfaction. Journal of Environmental Psychology, 17(1), 47-57. doi: http://dx.doi.org/10.1006/jevp.1996.0038

Anderson, I., \& Weidemann, S. (1997). Developing and utilizing models of resident satisfaction. In G. Moore \& R. Marans (Eds.), Advances in Environment, Behavior, and Design (Vol. 4, pp. 287-314). New York: Plenum Press.

Berkoz, L., \& Kellekci, O. L. (2007). Mass housing: Residents satisfaction with their housing and environment. Open House International, 32(1), 41-49.

Bonaiuto, M., Aiello, A., Perugini, M., Bonnes, M., \& Ercolani, A. P. (1999). Multidimensional perception of residential environment quality and neighbourhood attachment in the urban environment. Journal of Environmental Psychology, 19(4), 331-352. doi: 10.1006/jevp.1999.0138 
Bonaiuto, M., Fornara, F., \& Bonnes, M. (2003). Indexes of perceived residential environment quality and neighbourhood attachment in urban environments: a confirmation study on the city of Rome. Landscape and Urban Planning, 65(1-2), 43-54. doi: 10.1016/s0169-2046(02)00236-0

Canter, D., \& Rees, K. (1982). A multivariate model of housing satisfaction. Applied Psychology, 31(2), 185-207. doi: 10.1111/j.1464-0597.1982.tb00087.x

Dasimah, O., Faizul, A., Fatimah, Y., Hazlina, H., Naasah, N., \& Ishak, C. A. (2011). The Impacts of Off-Campus Students on Local Neighbourhood in Malaysia. World Academy of Science, Engineering and Technology(58), 7.

Fleury-Bahi, G., Félonneau, M.-L., \& Marchand, D. (2008). Processes of Place Identification and Residential Satisfaction. Environment and Behavior, 40(5), 669-682. doi: 10.1177/0013916507307461

Fornara, F., Bonaiuto, M., \& Bonnes, M. (2010). Cross-Validation of Abbreviated Perceived Residential Environment Quality (PREQ) and Neighborhood Attachment (NA) Indicators. Environment and Behavior, 42(2), 171-196. doi: $10.1177 / 0013916508330998$

Kahana, E., Lovegreen, L., Kahana, B., \& Kahana, M. (2003). Person, Environment, and Person-Environment Fit as Influences on Residential Satisfaction of Elders. Environment and Behavior, 35(3), 434-453. doi: $10.1177 / 0013916503035003007$

Kahrik, A., Leetmaa, K., \& Tammaru, T. (2012). Residential decision-making and satisfaction among new suburbanites in the Tallinn urban region, Estonia. Cities, 29(1), 49-58. doi: 10.1016/j.cities.2011.07.005

Mohit, M. A., Ibrahim, M., \& Rashid, Y. R. (2010). Assessment of residential satisfaction in newly designed public low-cost housing in Kuala Lumpur, Malaysia. Habitat International(34), 10.

Muslim, M. H., Karim, H. A., \& Abdullah, I. C. (2012a). Challenges of Off-Campus Living Environment for NonResident Students' Well-Being in UiTM Shah Alam. Procedia - Social and Behavioral Sciences, 50(0), 875-883. doi: 10.1016/j.sbspro.2012.08.089

Muslim, M. H., Karim, H. A., \& Abdullah, I. C. (2012b). Satisfaction of Students' Living Environment between OnCampus and Off-Campus Settings: A Conceptual Overview. Procedia - Social and Behavioral Sciences, 68(0), 601614. doi: http://dx.doi.org/10.1016/j.sbspro.2012.12.252

Muslim, M. H., Karim, H. A., Abdullah, I. C., \& Ahmad, P. (2013). Students' Perception of Residential Satisfaction in the Level of Off-Campus Environment. Procedia - Social and Behavioral Sciences, 105(0), 684-696. doi: http://dx.doi.org/10.1016/j.sbspro.2013.11.071

Nurul 'Ulyani, M. N., Nor' Aini, Y., \& Nazirah, Z. A. (2011). Student residential satisfaction in research universities. Journal of Facilities Management, 9(3), 200-212.

Oktay, D., \& Rustemli, A. (2011). The Quality of Urban Life and Neighborhood Satisfaction in Famagusta, Northern Cyprus

Investigating Quality of Urban Life. In R. W. Marans \& R. J. Stimson (Eds.), (Vol. 45, pp. 233-249): Springer Netherlands.

Parkes, A., Kearns, A., \& Atkinson, R. (2002). What makes people dissatisfied with their neighbourhoods? Urban Studies, 39(13), 13-38.

Weidemann, S., \& Anderson, J. (1985). A conceptual framework for residential satisfaction. In I. Altman \& W. C. (Eds.), Home Environments (pp. 153-182). New York: Plenum Press. 
Muslim, M.H., et.al. / Asian Journal of Behavioural Studies (AjBeS), 3(10) Mar / Apr 2018 (p.11-22)

Werner, C. M., \& Altman, I. (1985). Home environments (Vol. Human behavior and environment). London: Plenum Press. 